\title{
PEDAGOGY
}

\section{АСПЕКТИ ПЕДАГОГІЧНОГО ЕСТЕТИЧНОГО ВИХОВАННЯ СТУДЕНТІВ МЕДИЧНОГО УНIВЕРСИТЕТУ}

\author{
Бойчук Віра Богданівна, к. мед. н. \\ Украӥна, м. Івано-Франківськ, Івано-Франківський національний медичний університет
}

DOI: https://doi.org/ 10.31435/rsglobal_ws/30082018/6070

\section{ARTICLE INFO}

Received: 14 July 2018

Accepted: 26 August 2018

Published: 30 August 2018

\section{KEYWORDS}

aesthetics, aesthetic culture, aesthetic education.

\begin{abstract}
The article talks about the problem of student aesthetic education as a component of modern medical education. The survey of students at the Ivano-Frankivsk National Medical University illustrated the role students assign to the aesthetic education in their personal and professional growth as well as their estimate of pedagogical effect on the development of aesthetic culture.
\end{abstract}

Citation: Бойчук Віра Богданівна. (2018) Aspekty Pedahohichnoho Estetychnoho Vykhovannia Studentiv Medychnoho Universytetu World Science. 8(36), Vol.3. doi: 10.31435/rsglobal_ws/30082018/6070

Copyright: (C) 2018 Бойчук Віра Богданівна. This is an open-access article distributed under the terms of the Creative Commons Attribution License (CC BY). The use, distribution or reproduction in other forums is permitted, provided the original author(s) or licensor are credited and that the original publication in this journal is cited, in accordance with accepted academic practice. No use, distribution or reproduction is permitted which does not comply with these terms.

Вступ. У формуванні особистості людини, іiі духовності та внутрішнього світу основну роль відіграє естетичне виховання [1]. Культура поведінки, вихованість, тактовність- важливі компоненти у спілкування лікаря і пацієнта, що позитивно впливає на моральний та фізичний стан хворого, що і можна назвати терміном духовно-естетична медицина [2,3].

На сьогоднішній день методи цієї нової медичної практики стрімко розвиваються i пропонуються різні технології у вигляді музичних салонів, косметичних кабінетів та груп психологічного впливу [4,5]. Але не дивлячись на багатогранність наукових досліджень та матеріалів присвячених естетичному вихованню, зокрема студентів медичних університетів, ця тема потребує постійного удосконалення та розвитку. Тому, для детальнішого вивчення та виявлення різних установок студентів медичних вузів по їхньому сприйняттю естетичного виховання та освіти пропонуються опитування, диспути, анкетування та інтерв'ювання [6].

Результати дослідження. 3 метою виявлення інтересу студентів Івано-Франківського національного медичного університету (ІФНМУ) до вивчення естетичних предметів була розроблена анкета, опитано 150 студентів 1, 2 та 3 курсів ІФНМУ та проведено відповідний аналіз, де буди виявлені загальна культура, естетичні знання та навики, мотивація естетичної діяльності, визначення самооцінки та вміння оцінити художній твір.

Під час дослідження студенти повинні були визначити та сформувати власне бачення цілі і завдання естетичної освіти та виховання, аргументовано сформулювати та відповісти про зв'язок естетичної та професійної культури лікаря, пояснити свою перевагу в питаннях мистецтва та культурного дозвілля. Під час проведених досліджень визначався рівень естетичної культури студентів та використання часу для свої духовних потреб.

Так, проводити вільний час в колі друзів хочуть $62 \%$ студентів, музиці, танцям, поезії та читанню надають 47\% опитуваних, займатися спортом люблять 28\%. Дуже великий відсоток 
(69\%) не відвідують великі культурно-масові заходи - концерти класичної музики, театральні вистави, художні виставки. 37 \% відвідують їх дуже рідко, а 21 \% відверто заявили, що їм там не цікаво. Першокурсники проявили більшу зацікавленість, 81 \% висловилися, що хотіли б частіше відвідувати подібні культурно-мистецькі заходи. На запитання чим являється мистецтво в житті людини 33\% студентів відповіли, що це для розваги і відпочинку. 3 допомогою мистецтва мріють розширити свій загальний рівень, отримати різного роду інформацію хочуть 39 \%. Вийти за межі буденності за допомогою мистецтва бажають 28\% і дуже мала кількість (9 \%) студентів відповіли, що мистецтво зі всіма його жанрами приносить їм естетичне задоволення. У сфері художніх інтересів студентів домінувало кіно (42\%), музика (39\%) була на другому місці, поезією та літературою захоплювалось 12\% першокурсників, театром - 9\%, а малярством та живописом тільки $6 \%$.

При опитуванні студентів на літературну тематику, в поле їхньої зацікавленості входили твори, в яких висвітлюється важливі соціальні та морально-психологічні проблеми. В більшості студенти згадували і називали імена та твори тих письменників, яких вчили в школі. Лише 39 \% опитуваних згадали про письменників новітньої та зарубіжної літератури. На запитання що вони прочитали за останній місяць 91 \% відповіли, що це були навчальні посібники та наукова література. Дослідження також виявило, що загальна ерудиція студентів у сфері художньої літератури дуже низька, орієнтується в питаннях культури та мистецтва лише $22 \%$ опитуваних. Про існування всесвітньо відомих творів знають 19 \%, художників зі світовим визнанням згадали $34 \%$ студентів, художників середньовіччя- 24\% i лише $12 \%$ студентів орієнтувалися в творах мистецтва маловідомих авторів.

Покращення ситуації бажане і в питаннях естетики. Так, 87 \% опитаних вважають, що категорії “моральне" і “естетичне” є синонімами, а 94 \% що “спотворене” і “гротескне” не $\epsilon$ естетичними поняттями. При аналізі художньої літератури, фільмів самим важливим являється сюжет- назвали 39\%. Характер та гру акторів 18 \%, відображення моральних ідеалів- 13\%, переживання сильних емоції-11\% і лише 5\% студентів назвали високу художність твору.

На завдання творчого характеру назвати свій любимий твір мистецтва і пояснити його вибір 20\% не змогли дати відповіді, і 65\% назвали відомі шкільні твори, але не змогли пояснити їх перевагу. Гарно, з поясненням любимих творів, були не тільки книги, фільми, але i полотна художників, музичні твори композиторів. Позитивну відповідь по цих питаннях дали 33\%. Приємно відмітити, що свої відповіді студенти насичували розгорнутими поясненнями 3 елементами естетичного аналізу, де відчувались їхня щира захопленість цими творами і наявність таланту в естетичні оцінці і 75 \% визнають потребу в необхідності естетичних смаків у сфері культури та мистецтва. Для глибокого сприйняття i розуміння мистецтва 68\% опитуваних переконані, що оцінку і аналіз художнього твору може дати кожен, тому, що вони створені для всіх людей, для критиків, знавців, професіоналів.

В процесі анкетування та опитування вияснилося, що художньо-естетичними навиками володіють багато студентів, тому що до поступлення в університет займалися та брали участь в музичних, художніх школах та різних гуртках та студіях. Відрадно те, що 87 \% першокурсників хотіли би продовжувати ці заняття, якби їм дозволяв вільний час.

До визначення свого естетичного рівня розвитку студенти віднеслись досить об’ єктивно, 77 \% оцінюють його як середній. Високу оцінку поставили собі 13 \%, а відізвались критично про свій рівень розвитку загальної культури 10 \%. Рівень власних естетичних смаків високо оцінили $14 \%$. Середнім назвали 78\% опитуваних, а низькими- 8\%, але усі без вийнятку опитувані студенти виявили бажання удосконалювати свій загальний культурно-естетичний рівень.

Студентам першокурсникам було запропоновано дати своє пояснення взаємозв'язку професійності медика і його загально-культурного рівня. На думку всіх опитаних спеціалістмедик повинен володіти і керуватись високою культурою мислення і мови, ерудицією у сфері мистецтва і розвинутим художнім смаком. Аналізуючи це питання 79 \% студентів відзначили, що у лікаря все повинно бути на відповідному високому рівні, що лікар- професіонал повинен бути всесторонньо розвинутим, що естетична культура підвищує престиж лікаря в очах пацієнта.

Вкрай насторожує, що жоден із опитуваних студентів не приділяє уваги ролі естетичного виховання в системі університетської освіти, 88\% опитаних зводять цей процес до самоосвіти, а хтось вважає відповідальними за нього школу і батьків. У зв'язку з цим становить інтерес реакція студентів на питання про доцільність введення в вузівську програму дисциплін, які матимуть на меті вдосконалення естетичної культури студентів. 28 \% опитуваних першокурсників висловили своє бажання вивчати такого роду навчальні предмети і відмітили ïx важливість для всебічного розвитку людини. Про бажання розширити свій естетичний 
кругозір в період навчання у вищій школі заявили багато з опитаних студентів, але більшість 3 них $(75 \%)$ висловилися проти будь-яких доповнень до навчального плану через досить високу напруженість навчального процесу. На думку ж $18 \%$ опитаних освітній процес у вузі повинен обмежуватися формуванням професійних знань і навичок.

Висновки. Естетичне виховання являе собою безперервний процес оволодіння індивідом естетичного досвіду, знання і навичок. Недооцінка його значення для особистісного формування майбутніх фахівців, недостатня увага до нього з боку педагогів, і досі домінуюча практика в більшості навчальних закладів поділу навчальних предметів на «важливі» $\mathrm{i}$ «неважливі» призводять до того, що багато студентів виводять естетичне виховання за рамки педагогічного та виховного процесів.

Отримані в ході дослідження результати свідчать, що у більшості першокурсників $\epsilon$ усвідомлене прагнення підвищувати свій загальнокультурний рівень, реалізовувати естетичні потреби як в спілкуванні з мистецтвом, так і в творчій діяльності. За відповідями на ряд питань анкети можна судити, що багато хто з опитуваних студентів невисокої думки про можливості педагогічного впливу на процес естетичного виховання і покладаються, головним чином, на власні сили. Однак, активно самоосвітою займаються лише $19 \%$ від числа опитаних, решта ж (81\%) не знаходять для цього вільного часу. Спеціалізована література 3 проблем мистецтва $\mathrm{i}$ естетики входить в коло читання у 4\% студентів; «дуже рідко» до неї звертаються 54\%; а взагалі її не читають $42 \%$ опитуваних.

Головним висновком проведеного дослідження $є$ виявлення наявності у студентів живого інтересу до естетичного світу, бажання збагачувати придбаний естетичний досвід, розвивати i вдосконалювати естетичний смак і культуру. У переважної більшості студентів (88\%) люди 3 розвиненим естетичним смаком викликають почуття поваги. Багато першокурсників $(77 \%)$ жалкують, що не змогли отримати повноцінної естетичної освіти, а на питання чи хотіли б вони дати його своїм майбутнім дітям - всі вони відповідають ствердно “так”.

Таким чином, у більшості опитуваних студентів досить високий рівень сприйняття естетичної культури. У зв'язку з цим необхідно звернути особливу увагу викладачів на вирішення проблеми естетичного виховання та освіти, створити педагогічні умови, які дозволять створити сприятливе середовище для розвитку естетичної свідомості студентів, більш інтенсивно використовувати естетичний потенціал навчальних предметів гуманітарного циклу.

\section{ЛITEPATУРА}

1. Арановская И. В. Подготовка специалиста как социокультурная проблема // Высшее образование в России. 2002. № 4. С. 115-119.

2. Аронов Д. В. Эстетическое воспитание в системе высшего образования России как средство оптимизации кросс-культурного академического взаимодействия преподавателей и студентов в ходе Болонского процесса // Образование и общество. 2013. № 2 (79). С. 28-30.

3. Балахонов А. В. Фундаментализация высшего медицинского образования // Вестник СанктПетербургского государственного университета. 2006. Сер. 11. Вып. 1. С. 136-141.

4. Верб М. А. Эстетическое развитие личности в контексте культуры // Вестник Северо-Западного отделения Российской академии образования. 2000. Вып. 5. С. 64-73.

5. Киященко Н.И. Вопросы формирования системы эстетического воспитания. - М.: Искусство, 1971. -291 с.

6. Царева Л. М. Опыт применения интегративного подхода к организации эстетического воспитания студентов в вузе // Социально-экономическая эффективность результатов исследований молодых ученых в области образования. - М.: Директ-Медиа, 214. - С. 243-248. 